\title{
NOTES
}

\section{Two-Dimensional Thin-Layer Chromatography for Amino Acid Analysis of Bacterial Cell Walls}

\author{
J. J. HARPER AND G. H. G. DAVIS \\ Department of Microbiology, University of Queensland, St. Lucia, Brisbane, Australia \\ Good separation of bacterial cell wall amino acids, including the isomers of \\ diaminopimelic acid, was obtained by two-dimensional thin-layer chromatogra- \\ phy, using commercial cellulose-coated aluminum sheets with isopropanol-acetic \\ acid-water (75:10:15, vol/vol) and methanol-pyridine-10 $\mathrm{N}$ hydrochloric \\ acid-water $(64: 8: 2: 14, \mathrm{vol} / \mathrm{vol})$ as the first and second solvents, respectively.
}

Cell wall analysis is an established chemotaxonomic method in bacterial systematics. The analyses can be made at various levels of technological sophistication, depending upon the choice, skill, and resources of the operator. Most systematic work still relies upon paper chroma- tography $(1,2,5)$, a time-consuming and bulky process which, when used for amino acid analyses, needs extra work to identify the LL or meso/ DD forms of diaminopimelic acid (2). Although one-dimensional thin-layer chromatography has been recommended for some rapid screening and

TABLE $1 . R_{f}$ and $R_{A l a}$ values for 15 amino acids in solvent 1 (isopropanol) and solvent 2 (methanol)

\begin{tabular}{|c|c|c|c|c|c|}
\hline \multirow{2}{*}{$\begin{array}{l}\text { Spot } \\
\text { no. }\end{array}$} & \multirow{2}{*}{ Amino acid } & \multicolumn{2}{|c|}{ Solvent 1} & \multicolumn{2}{|c|}{ Solvent 2} \\
\hline & & $R_{f}$ & $R_{\text {Ala }}$ & $R_{f}$ & $R_{\text {Alu }}$ \\
\hline 1 & Leucine & 0.60 & 2.37 & 0.83 & 1.13 \\
\hline 2 & Valine & 0.46 & 1.82 & 0.79 & 1.07 \\
\hline 3 & Phenylalanine & 0.46 & 1.82 & 0.74 & 1.01 \\
\hline 4 & Alanine & 0.25 & 1.00 & 0.73 & 1.00 \\
\hline 5 & Threonine & 0.19 & 0.76 & 0.61 & 0.83 \\
\hline 6 & Glutamic acid & 0.19 & 0.76 & 0.55 & 0.75 \\
\hline 7 & Serine & 0.12 & 0.32 & 0.50 & 0.68 \\
\hline 8 & Lysine & 0.07 & 0.18 & 0.47 & 0.64 \\
\hline 9 & Glycine & 0.13 & 0.34 & 0.45 & 0.61 \\
\hline 10 & Arginine & 0.08 & 0.21 & 0.42 & 0.57 \\
\hline 11 & Aspartic acid & 0.11 & 0.29 & 0.38 & 0.52 \\
\hline 12 & Ornithine & 0.06 & 0.16 & 0.37 & 0.51 \\
\hline 13 & LL-DAP ${ }^{b}$ & 0.01 & 0.03 & 0.34 & 0.46 \\
\hline 14 & Histidine & 0.01 & 0.18 & 0.31 & 0.42 \\
\hline 15 & meso/DD-DAP & 0.01 & 0.05 & 0.26 & 0.35 \\
\hline
\end{tabular}

${ }^{a}$ Numbers refer to those given in Fig. 1 .

${ }^{b}$ DAP, Diaminopimelic acid. 


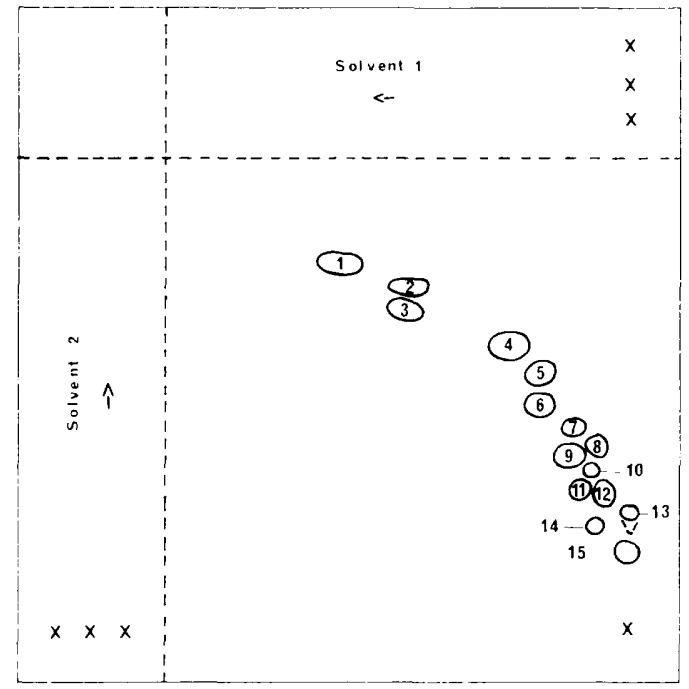

$x=$ Origins

FIG. 1. Diagrammatic tracing of a two-dimensional chromatogram of a mixture containing $1 \mathrm{mg}$ of each of 15 amino acids per ml. For identification of spot numbers, see Table 1 . identification purposes (6), it does not seem to have become popular with taxonomists as a twodimensional technique. We have found the following combination of methods simple, sensitive, and reliable.

Two glass containers able to accommodate 20$\mathrm{cm}^{2}$ sheets are required. We use Shandon thinlayer chromatography tanks ( 30 by 22 by $13 \mathrm{~cm}$ ). To ensure saturation of the tank atmosphere by the solvent, two walls of each tank are lined internally with blotting paper, and ca. $100 \mathrm{ml}$ of solvent is put into the tank $24 \mathrm{~h}$ before runs are to be made.

Cellulose-coated aluminum sheets ( 20 by 20 cm; Merck catalogue no. 5552) are marked with seven origin points $1.5 \mathrm{~cm}$ from two sheet edges (see Fig. 1), and pencil lines are made $15.5 \mathrm{~cm}$ from, and parallel to, those sheet edges. Fully hydrolyzed cell walls are prepared from ca. 10 mg (dry weight) of cells by the hot trichloroacetic acid-trypsin rapid-screening method of Schleifer and Kandler (5). Each two-dimensional analysis requires 2 to $4 \mu \mathrm{l}$ of hydrolysate, and the sample spot size must be kept minimal. The strips, $4.5 \mathrm{~cm}$ wide, marked on the sheet (see Fig. 1) are used to make one-dimensional

TABLE 2. Cell wall amino acid analysis results for selected gram-positive bacteria ${ }^{a}$

\begin{tabular}{|c|c|c|c|c|c|c|c|c|c|c|}
\hline \multirow{2}{*}{ Organism } & \multicolumn{10}{|c|}{ Amino acids present in cell walls } \\
\hline & $\mathrm{Ala}$ & Glu & Lys & Asp & Gly & Ser & Orn & LL-DAP & meso-DD-DAP & DAB \\
\hline $\begin{array}{l}\text { Corynebacterium bovis } \\
\text { UQM } 554\end{array}$ & + & + & - & - & - & - & - & - & + & - \\
\hline $\begin{array}{l}\text { C. diphtheriae UQM } 889 \\
\text { (= NCTC 3984) }\end{array}$ & + & + & - & + & - & - & - & - & + & - \\
\hline $\begin{array}{l}\text { C. michiganense UQM } \\
1373\end{array}$ & + & + & - & + & + & - & - & - & - & + \\
\hline $\begin{array}{l}\text { Actinomyces bovis GD } \\
\quad 186\end{array}$ & + & + & + & + & + & + & - & - & - & - \\
\hline $\begin{array}{l}\text { Propionibacterium pe- } \\
\text { tersonii GD } 431 \text { (= } \\
\text { ATCC 4870) }\end{array}$ & + & + & - & + & + & - & - & + & - & - \\
\hline $\begin{array}{l}\text { Brevibacterium linens } \\
\text { UQM } 26\end{array}$ & + & + & - & + & + & + & - & - & + & - \\
\hline $\begin{array}{l}\text { Erysipelothrix rhusiopa- } \\
\text { thiae GD } 208\end{array}$ & + & + & + & + & + & + & - & - & - & - \\
\hline
\end{tabular}

${ }^{a}$ Abbreviations: UQM, Culture Collection, Microbiology Department, University of Queensland, St. Lucia, Brisbane, Australia; GD, G. H. G. Davis, Microbiology Department, University of Queensland, St. Lucia, Brisbane, Australia; NCTC, National Collection of Type Cultures, Central Public Health Laboratory, London NW9 5HT, England; ATCC, American Type Culture Collection, Rockville, MD 20852, U.S.A.; Ala, alanine; Glu, glutamic acid; Lys, lysine; Asp, aspartic acid; Gly, glycine; Ser, serine; Orn, ornithine; DAP, diaminopimelic acid; DAB, diaminobutyric acid. Symbols: + present; -, not present. 
runs of the sample and control mixtures of standard amino acids in each solvent.

The first-dimension solvent is isopropanol-acetic acid-water (75:10:15, vol/vol) (5) and takes ca. $3 \mathrm{~h}$ to reach the $15.5-\mathrm{cm}$ mark. The chromatogram is then dried overnight in a ventilated hood at room temperature or, if speed is needed, in a ventilated oven at $105^{\circ} \mathrm{C}$ for a short time. The second solvent is methanol-pyridine-10 $\mathrm{N}$ hydrochloric acid- water $(64: 8: 2: 14, \mathrm{vol} / \mathrm{vol})(4)$ and takes ca. $1.25 \mathrm{~h}$ to reach the $15.5-\mathrm{cm}$ mark. Completed chromatograms are air-dried and visualized with $0.2 \%$ ninhydrin in acetone by spraying and heating at $105^{\circ} \mathrm{C}$.

Table 1 shows the $R_{f}$ and $R_{\text {Ala }}$ values for 15 amino acids, and Fig. 1 represents a tracing of a completed two-dimensional chromatogram of a mixture of the 15 acids. Figure 1 also shows the layout of origin points and solvent front lines and the tendency to tail in spot 13 . We have used these methods on a range of gram-positive bacteria (Table 2) and found them convenient, rapid, and accurate.

Hexosamines do not appear on these chromatograms, but this is no disadvantage since they do not normally assist classification. If needed, they can be visualized (but not separated) with Ehrlich reagent (3) after a one-dimensional run in solvent 1 . A standard sample of diaminobutyric acid was not available, but it was detected in the extract of Corynebacterium michiganense as a gray spot which did not leave the origin in solvent 1 but ran slightly ahead of LL-diaminopimelic acid in solvent 2 . Unless very stringent methods of cell wall preparation are used, the hydrolyzed extracts always contain traces of membrane and other components (5). The sensitivity of thin-layer chromatography is so much greater than that of paper chromatography that such traces are always detected. In gram-positive bacteria the number of significant cell wall amino acids seldom exceeds three or four, and they are readily recognized by their larger and denser spots. As noted by Keddie and Cure (2), discrepancies occur between the results of different workers using the same bacteria because of differences in methods. The present method offers the advantages of being fast, of using simple chromatographic equipment, and of producing discrete spots from very small samples. We have found the one-dimensional thinlayer chromatography method for cell wall sugars of Staneck and Roberts (6) to be satisfactory.

We thank Jenny MacIvor for valuable technical help.

\section{REPRINT REQUESTS}

No reprints available.

\section{LITERATURE CITED}

1. Becker, B., M. P. Lechevalier, R. E. Gordon, and H. A. Lechevalier. 1964. Rapid differentiation between Nocardia and Streptomyces by paper chromatography of whole-cell hydrolysates. Appl. Microbiol. 12:421-423.

2. Keddie, R. M., and G. L. Cure. 1977. The cell wall composition and distribution of free mycolic acids in named strains of coryneform bacteria and in isolates from various natural sources. J. Appl. Bacteriol. 42:229-252.

3. Partridge, S. M., and R. G. Westall. 1948. Filter paper partition paper chromatography of sugars. 1. General description and application to the quantitative analysis of sugars in apple-juice, egg-white and foetal blood of sheep. Biochem. J. 42:238-250.

4. Rhuland, L. E., E. Work, R. F. Denman, and D. S. Hoare. 1955. The behaviours of the isomers of $\alpha \epsilon$ diaminopimelic acid on paper chromatograms. J. Am. Chem. Soc. 77:4844-4846.

5. Schleifer, K. H., and O. Kandler. 1972. Peptidoglycan types of bacterial cell walls and their taxonomic impli. cations. Bacteriol. Rev. 36:407-477.

6. Staneck, J. C., and G. D. Roberts. 1974. Simplified approach to identification of aerobic actinomycetes by thin-layer chromatography. Appl. Microbiol. 28:226231. 